\title{
Engines of liberation redux when home appliances prices are endogenous
}

\author{
Sebastien Buttet · Veronika Dolar
}

Published online: 12 September 2014

(C) Institut für Arbeitsmarkt- und Berufsforschung 2014

\begin{abstract}
We propose a model of the household where the transmission mechanism between home appliances and women's labor supply is identical to the one in Greenwood et al. (2005b) with one important exception. We explicitly model firms' pricing and output choices in the appliances sector and thus, the price of home appliances is determined endogenously by the laws of supply and demand rather than being taken exogenously from outside the model. We use this new framework to characterize the general equilibrium effects of rising household wages on the price of home appliances, and thus ultimately women's labor supply. The ratio between the price of home appliances and household wages declines following a rise in the wage level, which leads to widespread adoption of home appliances and increased labor force participation of married women. A numerical example shows that rising wages account for half of the increase in participation of married women between 1960 and 1970.
\end{abstract}

\section{Einfluss des Preises von Haushaltsgeräten auf die Erwerbsbeteiligung von Frauen}

Zusammenfassung In diesem Artikel schlagen wir ein Haushaltsmodell vor, in welchem der Übertragungsmechanismus zwischen Haushaltsgeräten und dem Angebot an weiblichen Arbeitskräften mit einer wichtigen Ausnahme

We thank two anonymous referees, Myong-Hun Chang, and Alice Schoonbroodt for their comments.

V. Dolar, $\mathrm{PhD}(\varangle)$

Long Island University, Brookville, NY, USA

e-mail: veronika.dolar@liu.edu

S. Buttet, $\mathrm{PhD}$

City University of New York, Guttman Community College,

50 40th W, New York, NY 10018, USA

e-mail: sebastien.buttet@guttman.cuny.edu dem von Greenwood et al. (2005b) entspricht. Wir modellieren explizit die Preis- und Produktionsentscheidungen der Unternehmen im Haushaltsgerätesektor sowie Branchendynamiken. Demzufolge wird der Preis von Haushaltsgeräten endogen von den Gesetzen von Angebot und Nachfrage bestimmt und nicht exogen außerhalb des Modells. Wir nutzen diesen neuen Ansatz, um die allgemeinen Gleichgewichtseffekte steigender Haushaltseinkommen auf die Preise von Haushaltsgeräten und letztlich das Angebot an weiblichen Arbeitskräften zu bestimmen. Unser wichtigstes Ergebnis ist, dass das Verhältnis zwischen dem Preis von Haushaltsgeräten und Haushaltseinkommen nach einem Anstieg des Lohnniveaus sinkt, was wiederum zu einer steigenden Verwendung von Haushaltsgeräten und einer steigenden Erwerbsbeteiligung verheirateter Frauen führt. Demnach sind steigende Marktlöhne für knapp die Hälfte des Anstiegs der Erwerbsbeteiligung verheirateter Frauen zwischen 1960 und 1970 verantwortlich.

\section{Introduction}

Recent research in family economics emphasizes households' adoption of productivity-enhancing technology at home (home appliances) as a key catalyst for women's emancipation during the twentieth century, potentially accounting for the surge in labor force participation of married women (Greenwood et al. 2005b) (later GSY), higher divorce rates (Greenwood and Guner 2008), as well as changes in fertility decisions (Greenwood et al. 2005a). In the aforementioned papers, a sharp decline in the price of home appliances follows from total factor productivity growth in the household sector and the adoption of new capital allows households (married women) to produce home goods with less time. Embedding Becker's (1991) unitary framework of family 
economics into dynamic macroeconomic models, families are now faced with a joint decision. First, should they adopt home appliances in the current period or wait for a lower price? In GSY, the head of the household must also decide whether the woman should work in the market place or not.

The quantitative analysis in GSY suggests important interaction effects between home appliances adoption and labor supply. Technological progress in the household sector alone can account for more than half of the rise in female labor force participation. In contrast, narrowing of the gender gap alone accounts for only ten percentage points. In other words, the elasticity of female labour supply is low for households who choose not to adopt, while as more households adopt the new technology at home, the responsiveness of female labor supply to a narrowing in the gender gap increases. Recent empirical work also confirmed that the mechanism in GSY is supported by the data. For example, Cavalcanti and Tavares (2008) use time-series data on the price of home appliances in OECD countries for the period between 1975 and 1999 to show that a decrease in the relative price of appliances had a positive and signicant effect on women's labor force participation in OECD countries. Coen-Pirani et al. (2010) study micro-data from the 1960 and 1970 U.S. Census and find that ownership of washing machines, dryers, and freezers all contributed to the increase of the participation rate of married women in the labor market. Cardia (2010) analyzes the 1940 and 1950 U.S. county level Census data. She finds that the adoption of modern appliances such as modern stoves and refrigerators did not have a signicant impact on women's labor participation rates but helped increase womens participation in professional occupations.

In this paper, we propose a general equilibrium model of the household where the transmission mechanism between home appliances and women's labor supply is identical to the one in GSY with one important exception. We explicitly model firms' pricing and output choices in the appliances sector as well as industry dynamic and thus, the key variable in GSY and the other aforementioned papers - the price of home appliances - is determined endogenously by the laws of supply and demand rather than being taken exogenously from outside the model. We use this new framework to characterize the general equilibrium effects of rising household wages on the price of home appliances, and thus ultimately women's labor supply.

The following mechanisms determine the equilibrium value of home appliances prices. On the one hand, given our choice of utility function where home appliances are a normal good, the demand for home appliances shift outward following a rise in household wages which leads to higher prices for home appliances. On the other hand, there are two forces pushing home appliances prices down. First and as in GSY, total factor productivity in the appliances sector grows at an exogenously given rate. Second, we assume that competition in the home appliances sector is imperfect and we model the strategic interaction between firms as a Cournot game. As the market size of the home appliances sector increases, short-term profit opportunities attract new entrants which shifts supply outward and drive the price of home appliances further down.

Our main result is that the ratio between the price of home appliances and household wages declines following a rise in the wage level, which in turn leads to greater adoption rate and labor force participation of married women. As such, a new mechanism emerges where total factor productivity in all sectors of the economy affects the decision of women to work. This new result is interesting since others have shown elsewhere that women's labor force participation decision depends on the earning gap between husband and wife but is unaffected by technological progress and its effect on the level of household wages (Benhabib et al. (1991) or Jones et al. 2003). Here, because rising wages indirectly make the home technology more affordable, married women decide to join the work force even though the earning gap with their husband is unchanged.

Our mechanism linking households' wages to rising labor force participation of married women rests upon the assumption that home appliances are a normal good. Empirical studies show that a positive relationship exists between income and durable goods although the magnitude of income elasticity varies depending on the context. At the business cycle frequency, the seminal paper by Bar-Ilan and Blinder (1988) shows that expenditures on durables display very large shortrun elasticity to changes in permanent income. Research by Dubin and McFadden (1984) and Reiss and White (2005) jointly estimate the demand for appliances and the demand for electrity. Conditional on the stock of home appliances, they show that electricity demand is not very sensitive to variations in income but to the extent that income affects electricity consumption, it works through households' choices of appliances rather than through utilization behavior. More directly related to our study, Miller (1960) estimates a demand function for refrigerators in the U.S. using cross-section data at the state level between 1930 and 1940 and finds a positive effect of individual income. Day (1992) shows that richer households in Canada adopted home appliances first. Finally, Cardia (2010) discusses potential endogeneity problems in estimating the impact of income on women's labor supply decision. Wealthy counties have better infrastructures, generate higher incomes which can buy more modern appliances and can also offer more opportunities for women.

The remainder of the paper is organized as follows. In the next section, we present our model and define an equilibrium. In Sect. 3, we derive the main qualitative results of the paper. In Sect. 4, we present a numerical example to analyze the impact of rising household wages on labor force participation of married women between 1960 and 1970. We offer concluding remarks in Sect. 5. 


\section{The model}

We present a general equilibrium model of the family with a continuum of households and firms that operate in the home appliances and market good sectors.

\subsection{Households}

Preferences: Households consist of one man and one woman with preferences defined over consumption of a market composite good, $c_{t}$, home good, $c_{h t}$, and leisure of men and women, by $l_{t}^{m}$ and $l_{t}^{f}$. Market and home good are consumed as public goods; labor income is pooled; men and women have identical preferences and choose allocation of consumption and leisure jointly to maximize household utility: ${ }^{1}$

$$
\mu^{m} U\left(c_{t}, c_{h t}, l_{t}^{m}\right)+\mu^{f} U\left(c_{t}, c_{h t}, l_{t}^{f}\right)
$$

where $\left(\mu^{m}, \mu^{f}\right) \in(0,1)^{2}$ denote the bargaining power of men and women within the household with $\mu^{m}+\mu^{f}=1$.

Here we assume that individual preferences for men and women are given by $U(x, y, z)=\alpha \ln (x)+\beta \ln (y)+(1-$ $\alpha-\beta) \ln (z)$ implying that the household objective function in Eq. (1) is equal to:

$\alpha \ln \left(c_{t}\right)+\beta \ln \left(c_{h t}\right)+(1-\alpha-\beta)\left(\mu^{m} \ln \left(l_{t}^{m}\right)+\mu^{f} \ln \left(l_{t}^{f}\right)\right)$

where $(\alpha, \beta) \in(0,1)^{2}$ and $\alpha+\beta<1 .^{2}$

Market ability and matching: We denote by $\lambda_{m}$ and $\lambda_{f}$ men's and women's ability in the market place, respectively. ${ }^{3}$

\footnotetext{
${ }^{1}$ Even though Browning and Chiappori (1998) show that assumptions underlying the "the unitary model" (pooled income, identical preferences, and joint utility maximization) are rejected by the data, the unitary framework is still commonly used in macroeconomic models of the family (e.g., Jones et al. (2003), GSY, and the references hereinabove). As an alternative to the unitary model, Browning et al. (2011) develop the "collective" approach to family economics where individual members of a family - as opposed to the family as a whole act as core decision-makers. As a result, household behavior reflects Pareto-efficient decisions collectively reached by all family members. ${ }^{2}$ With the use of a simple static example, Jones et al. (2003) study what restrictions must be imposed on preferences so that improvements in the home technology lead to an increase in women's hours worked. One possibility is that home and market goods are complements. However, McGrattan et al. (1997) and Rupert et al. (2000) estimate that consumption of home and market goods are substitutes. When household preferences are unit-elastic as in our model, a decline in the price of home appliances can only affect women's labor supply if there is satiation in the home good. The home technology described hereinbelow, with only two qualities of durable goods and which is the same as in GSY, de facto generates satiation in the home good. As a result, declining home appliances prices lead to greater labor force participation of married women.

${ }^{3}$ The only source of household heterogeneity is market ability. In a slightly different but related context, Jones et al. (2011) show that the
}

We assume perfect assortative matching between husbands' and wives' market ability so that the man with the highest market ability is married to the woman with the highest market ability, the man with the second best market ability is married to the woman with the second best market ability and so on and so forth. ${ }^{4}$ We assume that the gender wage ratio between women and men, $\varphi=\frac{w_{f t}\left(\lambda_{f}\right)}{w_{m t}\left(\lambda_{m}\right)}$, is constant across households and less than one, although we do not explicitly model why women earn less than men in the workplace. ${ }^{5,6}$ In addition and in contrast to Jones et al. (2003), human capital accumulation is not an option here implying that market ability of men and women do not change over time.

Home good production: We assume that all housework is done by women. Inputs used in home production consist of stock of household durable goods, $d_{t}$, time spent on housework, $n_{t}$ and we denote by $\zeta_{t}$ labor-augmenting technological progress in the household sector. To model the concepts of adoption and diffusion and as in GSY, household durables are lumpy and labor is indivisible.

Two different Leontief (fixed-proportion) technologies are available to produce home goods. The first one which is labor-intensive uses one unit of durable goods and $\rho \eta$ of women's time to produce one unit of the home good with $0<\rho \eta<1$ and $\rho>1$. In contrast, if households adopt the labor-saving technology, $\kappa$ unit of home good can be produced using $\kappa$ unit of durable goods and $\eta$ of women's time with $\kappa>1$. In summary, if households do not buy home applian-

negative relationship between fertility and income in cross-sectional data can be obtained in two different ways. Women can differ in either their market ability or their preferences for children, though differences in market ability are easier identified by data.

${ }^{4}$ Burdett and Coles (1999) as well as Browning et al. (2011) find evidence of assortative matching in the marriage market, especially along the education dimension. A recent paper by Greenwood et al. (2014) analyses data from the United States Census Bureau and finds a rise in assortative mating. The authors propose a mechanism whereby a rise in assortative mating affects household income inequality.

${ }^{5}$ Differences in pay between men and women are well documented (e.g., Goldin (1990), Goldin (1997), and Blau and Kahn (2000)). Differences in pay between men and women can measure either the direct effects of wage discrimination (the payment of lower wages to one group despite equivalent training and work duties) or differences in unmeasured (by the econometrician) skills that are correlated with sex. These differences in skills themselves could be due to discrimination e.g., glass ceilings and marriage bars (Goldin 1990) or due to other, non-discriminatory, incentives for the development of skills across the sexes (e.g., specialization in the provision of home goods and child care).

${ }^{6}$ The assumption that the gender wage ratio is constant across households, which is also found in Greenwood et al. (2005), allows the model to be tractable analytically. Bar and Leukhina (2011) who estimate the joint distribution of earnings between men and women study the quantitative impact of decline in the price of home appliances and the gender wage gap on time allocation at home and in the workplace. They find that falling cost of home appliances affects allocation of time outside of the workforce the most, while reductions in the gender earnings gap affect married women decision to work the most. 
ces, women spent a fraction $\rho \eta$ of their time doing chores and home good production is equal to $c_{h t}^{1}=\min \{1, \zeta \rho \eta\}=1$ with $\zeta=\frac{1}{\rho \eta}$. On the other hand, when households buy home appliances, women devote a fraction $\eta$ of their time to home good production which is equal to $c_{h t}^{2}=\min \left\{\kappa, \zeta^{\prime} \eta\right\}=\kappa$ with $\zeta^{\prime}=\frac{\kappa}{\eta}$. Note that $c_{h t}^{2}>c_{h t}^{1}$ since $\kappa>1$.

Time Constraints: We assume different time constraints for men and women which are given by:

$$
\begin{aligned}
& l_{t}^{f}+t_{w}^{f} e_{t}+n_{t}\left(a_{t}\right)=1 \\
& l_{t}^{m}+t_{w}^{m}=1
\end{aligned}
$$

where $\left(t_{w}^{f}, t_{w}^{m}\right) \in(0,1)^{2}$ are fixed parameters representing the length of the workweek for men and women, respectively ${ }^{7}$; $a_{t} \in\{0,1\}$ denotes household's decision for appliances adoption and $e_{t} \in\{0,1\}$ the decision for women's work with $a_{t}=1$ when households buy home appliances and $e_{t}=1$ when women decide to work. ${ }^{8}$

The time spent by women on housework given the appliances adoption decision, $n_{t}\left(a_{t}\right)$, is equal to $n_{t}(1)=\eta$ when household buy home appliances and $n_{t}(0)=\rho \eta$ if they do not with $n_{t}(1)<n_{t}(0)$ since $\rho>1$. $^{9}$

Budget Constraint: The household budget constraint equates labor income to spending on market goods and home appliances:

$$
c_{t}+p_{a t} a_{t}=w_{m t}\left(\lambda_{m}\right)+w_{f t}\left(\lambda_{f}\right) e_{t}
$$

where $w_{m t}$ and $w_{f t}$ are the real market wage for men and women, respectively, $p_{a t}$ denotes the price of home appliances, and we normalize the price of the market good to one.

In the rest of the paper, we assume that markets wages are proportional to market ability implying that $w_{m t}\left(\lambda_{m}\right)=\lambda_{m} w_{t}$ and $w_{f t}\left(\lambda_{f}\right)=\lambda_{f} w_{t}$ with $w_{t}$ the real market wage. Given our assumptions that the gender wage ratio is constant across households and that we have perfect assortative matching in

\footnotetext{
${ }^{7}$ McGrattan and Rogerson (2004) study changes in hours worked for men and women since 1950. They find that women who are employed full-time work fewer hours compared to men employed full-time and that hours worked conditional on working has changed very little since 1950. Our assumption that men always work in the marketplace comes from the fact that men and women have the same productivity at home but men earn more than women in the market place even after controlling for differences in market ability.

${ }^{8}$ All decisions in the model, adoption and labor supply, are made at the extensive margin. This is without loss of generality and GSY shows that qualitative results go through when labor and household durables are divisible. See Jones et al. (2003) for a model where men and women decide how many hours to work, i.e. labor supply decisions are made at the intensive margin. Also selling appliances is not an option for households with $a_{t} \in\{0,1\}$.

${ }^{9}$ The time spent on house chores given the home appliances adoption decision can be written succinctly $n_{t}\left(a_{t}\right)=\eta\left(1+(\rho-1)\left(1-a_{t}\right)\right)$ and it is easy to check that $n_{t}(1)=\eta$ and $n_{t}(0)=\rho \eta$. It is also straightforward to check that women who buy appliances save on housework time, $n_{t}(1)-n_{t}(0)=\eta-\rho \eta=\eta(1-\rho)<0$, since the parameter $\rho>1$.
}

market ability between husband and wife, women's earnings are equal to a fraction of men's earnings with $w_{f t}\left(\lambda_{f}\right)=$ $\lambda_{f} w_{t}=\varphi \lambda_{m} w_{t}$. As a result, the budget constraint can be rewritten as:

$$
c_{t}+p_{a t} a_{t}=w_{t} \lambda_{m}\left(1+\varphi e_{t}\right)
$$

We are now able to formulate the household utility maximization problem. In every period, taking the price of laborsaving appliances $p_{a t}$ and the market wage $w_{t}$ as given, households where men's ability equals $\lambda_{m}$ choose market good consumption, $c_{t}$, home good consumption, $c_{h t}$, women's employment $e_{t} \in\{0,1\}$, whether to adopt home appliances $a_{t} \in\{0,1\}$, leisure of men and women $\left(l_{t}^{m}, l_{t}^{f}\right)$ to maximize the household joint utility in Eq. (2) subject to the budget and time constraints in Eqs. (3) and (5), respectively. That is:

$$
\begin{array}{r}
\max _{\left(c_{t}, c_{h t}, a_{t}, e_{t}, l_{t}^{m}, l_{t}^{f}\right)} \alpha \ln \left(c_{t}\right)+\beta \ln \left(c_{h t}\right)+(1-\alpha-\beta) \\
\left(\mu^{m} \ln \left(l_{t}^{m}\right)+\mu^{f} \ln \left(l_{t}^{f}\right)\right)
\end{array}
$$

s.t.

$$
\left\{\begin{array}{l}
c_{t}+p_{a t} a_{t}=w_{t} \lambda_{m}\left(1+\varphi e_{t}\right) \\
\text { if } \quad a_{t}=1, \text { then } \quad c_{h t}=\kappa \\
\text { if } \quad a_{t}=0, \text { then } \quad c_{h t}=1 \\
l_{t}^{f}+t_{w}^{f} e_{t}+\eta\left(1+(\rho-1)\left(1-a_{t}\right)\right)=1 \\
l_{t}^{m}+t_{w}^{m}=1 \\
a_{t} \in\{0,1\}, \quad e_{t} \in\{0,1\}, \quad c_{t} \geq 0, \quad 0 \leq l_{t}^{m} \leq 1, \\
0 \leq l_{t}^{f} \leq 1
\end{array}\right.
$$

\subsection{Firms}

\subsubsection{Appliances sector}

The appliances sector is oligopolistic and firms play a Cournot game. ${ }^{10}$ Home appliances are produced with a linear technology and operating firms incur a fixed cost, $\chi$, which creates natural entry barriers.

We let $y_{a, i, t}, Y_{a t}$, and $Y_{a,-i, t}$ represent the output of firm $i$, total output in the appliances sector, and the output of all firms except for firm $i$, respectively. Given the market wage and the demand for appliances, $p_{a t}\left(Y_{a t}\right)$, firm $i$ chooses output and employment level, $l_{a, i, t}$, to maximize profits taking as given $Y_{a,-i, t}$.

$$
\begin{gathered}
\max _{\left(y_{a, i, t}, l_{a, i, t}\right) \geq 0} \Pi_{a, i, t}=p_{a t}\left(Y_{a,-i, t}+y_{a, i, t}\right) y_{a, i, t}-w_{t} l_{a, i, t}-\chi \\
\text { s.t. } \quad y_{a, i, t} \leq A_{a t} l_{a, i, t}
\end{gathered}
$$

\footnotetext{
${ }^{10}$ In the Appendix, we provide evidence on the 4-firm concentration ratio supporting that competition in the home appliances industry is oligopolistic.
} 
where $A_{a t}$ represents total factor productivity in the appliances sector.

Since all firms have access to the same technology, we restrict our analysis to symmetric equilibrium where $y_{a, i, t}=$ $y_{a, t}$ for all $i$. Operating firms maximize profits when the following first-order condition is met:

$$
p_{a t}^{\prime}\left(Y_{a t}\right) y_{a, t}+p_{a t}\left(Y_{a t}\right)=\frac{w_{t}}{A_{a t}}
$$

In addition, the free-entry condition implies that operating firms make non-negative profits, while firms outside the market expect to make negative profits if they enter. The zero-profit condition is given by:

$$
p_{a t}\left(Y_{a, t}\right) y_{a, t}-\frac{w_{t} y_{a, t}}{A_{a t}}=\chi
$$

\subsubsection{Market sector}

The market sector is perfectly competitive and output is produced with a constant returns to scale technology. Given the market wage, firms choose the output level, $y_{m t}$, and labor input, $l_{m t}$, to maximize profits:

$$
\max _{\left(l_{m t}, y_{m t}\right) \in \mathfrak{R}_{+}^{2}} \Pi_{m t}=A_{m t} l_{m t}-w_{t} l_{m t}
$$

where $A_{m t}$ represents total factor productivity in the market sector. The solution to the firm's problem is given by $w_{t}=$ $A_{m t}$ implying that the labor demand is perfectly elastic and firms' profits are equal to zero.

\subsection{Equilibrium definition}

We denote by $a\left(\lambda_{m}, \frac{p_{a t}}{w_{t}}\right)$ and $e\left(\lambda_{m}, \frac{p_{a t}}{w_{t}}\right)$ the optimal household decision for appliances adoption and women's work in a $\lambda_{m}$ ability household. We let $f\left(\lambda_{m}\right)$ and $F\left(\lambda_{m}\right)$ be the probability and cumulative density function of men's ability, respectively.

The aggregate demand for home appliances in every pe$\operatorname{riod}, \mathcal{D}^{a}$, is the measure of households which adopts the new technology:

$$
\mathcal{D}^{a}=\int_{0}^{+\infty} a\left(\lambda_{m}, \frac{p_{a t}}{w_{t}}\right) f\left(\lambda_{m}\right) d \lambda_{m}
$$

where $f\left(\lambda_{m}\right)$ denotes the probability density function of men's market ability distribution.

On the other hand, women's and men's labor supply, $\mathcal{S}^{f}$ and $\mathcal{S}^{m}$, are equal to:

$$
\begin{array}{r}
\mathcal{S}^{f}=\int_{0}^{+\infty} \varphi \lambda_{m} e\left(\lambda_{m}, \frac{p_{a t}}{w_{t}}\right) f\left(\lambda_{m}\right) d \lambda_{m}, \\
\mathcal{S}^{m}=\int_{0}^{+\infty} \lambda_{m} f\left(\lambda_{m}\right) d \lambda_{m}
\end{array}
$$

Definition 1 Given an exogenous sequence for total factor productivity in market and appliances sectors, $\left\{\left(A_{m t}, A_{a t}\right)\right\}_{t=1}^{+\infty}$ and a market ability gender gap, $\varphi$, a general equilibrium for our economy is a sequence of prices $\left\{p_{a t}, w_{t}\right\}_{t=1}^{+\infty}$ and allocations for households, $\left\{\left(a_{t}, e_{t}\right)\right\}_{t=1}^{+\infty}$, and firms, $\left\{\left(y_{m t}, y_{a t}, l_{m t}, l_{a t}\right)\right\}_{t=1}^{+\infty}$, such that:

1. Given prices, households choose $\left\{\left(a_{t}, e_{t}\right)\right\}_{t=1}^{+\infty}$ to maximize utility (2) subject to the budget and time constraints (5). Firms in both sectors choose labor and output level, $\left\{\left(y_{m t}, y_{a t}, l_{m t}, l_{a t}\right)\right\}_{t=1}^{+\infty}$ to maximize profits and the zeroprofit condition in Eq. (8) is satisfied.

2. Labor and home appliances market clear: ${ }^{11}$
a. $l_{a t}+l_{m t}=\mathcal{S}^{f}\left(\frac{p_{a t}}{w_{t}}\right)+\mathcal{S}^{m}\left(\frac{p_{a t}}{w_{t}}\right)$

b. $Y_{a t}=\mathcal{D}^{a}\left(\frac{p_{a t}}{w_{t}}\right)$.

\section{Qualitative results}

To characterize the model qualitative properties for women's decision to work and household adoption decision of home appliances, we compare the utility $U\left(e_{t}, a_{t}\right)$ of a household of type $\lambda_{m}$ for all possible values for $a_{t}$ and $e_{t}$ :

$$
\left\{\begin{array}{l}
U(0,0)=\alpha \ln \left(w_{t} \lambda_{m}\right)+(1-\alpha-\beta)\left(\mu^{m} \ln \left(1-t_{w}^{m}\right)\right. \\
\left.+\mu^{f} \ln (1-\rho \eta)\right) \\
U(0,1)=\alpha \ln \left(w_{t} \lambda_{m}-p_{a t}\right)+\beta \ln (\kappa)+(1-\alpha-\beta) \\
\left(\mu^{m} \ln \left(1-t_{w}^{m}\right)+\mu^{f} \ln (1-\eta)\right) \\
U(1,0)=\alpha \ln \left(w_{t} \lambda_{m}(1+\varphi)\right)+(1-\alpha-\beta) \\
\left(\mu^{m} \ln \left(1-t_{w}^{m}\right)+\mu^{f} \ln \left(1-t_{w}^{f}-\rho \eta\right)\right) \\
U(1,1)=\alpha \ln \left(w_{t} \lambda_{m}(1+\varphi)-p_{a t}\right)+\beta \ln (\kappa) \\
+(1-\alpha-\beta)\left(\mu^{m} \ln \left(1-t_{w}^{m}\right)+\mu^{f} \ln \left(1-t_{w}^{f}-\eta\right)\right)
\end{array}\right.
$$

Let us analyze the employment decision of women who do not adopt home appliances first. Straightforward algebra reveals that $U(1,0) \leq U(0,0)$ if and only if $0<\varphi \leq \varphi_{2}$ where $\varphi_{2} \equiv\left(\frac{1-\rho \eta}{1-t_{w}^{f}-\rho \eta}\right)^{\frac{(1-\alpha-\beta) \mu}{\alpha}}-1$. In other words, women who do not buy home appliances do not work if the gender wage ratio is below a threshold value. Note that the inequality $\varphi \leq \varphi_{2}$ does not depend on the price of home appliances or men's ability. As a result, since the gender wage ratio $\varphi$ is constant due to our assumption of perfect assortative matching in ability between men and women, only one of the following (mutually exclusive) alternatives can be true. When $\varphi \leq \varphi_{2}$ all women who work bought home appliances. On the other hand, when $\varphi>\varphi_{2}$ all women that choose not to buy home appliances work. We formalize these results in the following lemma.

\footnotetext{
${ }^{11}$ Implicitly we assume that Walras' Law holds and thus chose not to include a market clearing condition for the goods market in our definition of competitive equilibrium.
} 
Lemma 1 If $\varphi \leq \varphi_{2}$ then $e_{t}=1 \Rightarrow a_{t}=1$.

Proof Suppose that $\varphi \leq \varphi_{2}$. Then $U(1,0) \leq U(0,0)$ implying $a_{t}=0 \Rightarrow e_{t}=0$. The contrapositive of $\left(a_{t}=0 \Rightarrow e_{t}=\right.$ $0)$ is $\left(e_{t}=1 \Rightarrow a_{t}=1\right)$. Hence, we showed the desired result: If $\varphi \leq \varphi_{2}$ then $e_{t}=1 \Rightarrow a_{t}=1$.

When $\varphi \leq \varphi_{2}$ we showed that buying home appliances is a necessary condition for women to join the labor force. Is buying home appliances also a sufficient condition for women to work? Without adding further restriction on the gender wage ratio, the answer is no. Suppose that $a_{t}=1$. Work is optimal $U(1,1) \geq U(0,1)$ if and only if $\varphi \geq\left(1-\frac{p_{a t}}{\lambda_{m} w_{t}}\right)\left[\left(\frac{1-\eta}{1-t_{w}^{f}-\eta}\right)^{\frac{(1-\alpha-\beta) \mu^{f}}{\alpha}}-1\right]$. The latter inequality implies that, conditional on buying home appliances, women with lower ability who are married to men with low market ability choose to work. On the other hand, women with high ability who are married to high ability men choose not to work because of the income effect of husband's wages.

Let us define $\varphi_{1} \equiv\left[\left(\frac{1-\eta}{1-t_{w}^{f}-\eta}\right)^{\frac{(1-\alpha-\beta) \mu}{\alpha}}-1\right]$ with $\varphi_{2}>\varphi_{1}>$ 0 . The next proposition shows that all women who buy home appliances work when the gender wage ratio is above a given threshold.

Lemma 2 If $\varphi \geq \varphi_{1}$ then $a_{t}=1 \Rightarrow e_{t}=1$.

Proof $U(1,1) \geq U(0,1)$ if and only if $\varphi \geq$ $\left(1-\frac{p_{a t}}{\lambda_{m} w_{t}}\right)\left[\left(\frac{1-\eta}{1-t_{w}^{f}-\eta}\right)^{\frac{(1-\alpha-\beta) \mu}{\alpha}}-1\right]$. For all values of $\frac{p_{a t}}{\lambda_{m} w_{t}}$, we have $\varphi_{1}>\left(1-\frac{p_{a t}}{\lambda_{m} w_{t}}\right)\left[\left(\frac{1-\eta}{1-t_{w}^{f}-\eta}\right)^{\frac{(1-\alpha-\beta) \mu^{f}}{\alpha}}-1\right]$. Hence, if one imposes $\varphi \geq \varphi_{1}, U(1,1) \geq U(0,1)$ implying that $e_{t}=1$ is the optimal work decision when $a_{t}=1$. Hence, we showed the desired result: If $\varphi \geq \varphi_{1}$ then $a_{t}=1 \Rightarrow e_{t}=1$.

When one combines the previous two lemmas, we get the result that the decision to work and the decision to adopt home appliances are equivalent when the gender wage ratio belongs to the interval $\left[\varphi_{1}, \varphi_{2}\right]$. That is $a_{t}=1 \Leftrightarrow e_{t}=1$ when $\varphi_{1} \leq \varphi \leq \varphi_{2}$. As a result, to fully characterize household decisions, it is enough to analyze the adoption decision by households and compare $U(1,1)$ to $U(0,0)$. The following proposition summarizes decisions of type- $\lambda_{m}$ households:

Lemma 3 (Households' Optimal Decisions) If $\varphi_{1} \leq \varphi \leq$ $\varphi_{2}$, then the optimal employment and adoption decisions of type- $\lambda_{m}$ households are given by:

$$
e\left(\lambda_{m}, \frac{p_{a t}}{w_{t}}\right)=a\left(\lambda_{m}, \frac{p_{a t}}{w_{t}}\right)=1 \Leftrightarrow \lambda_{m} \geq \hat{\lambda}_{m t}
$$

where the ability threshold $\hat{\lambda}_{m t} \equiv \frac{p_{a t}}{w_{t} \phi(\varphi)}$ and the function $\phi(\varphi)=1+\varphi-\left(\frac{1-\rho \eta}{1-t_{w}^{f}-\eta}\right)^{\frac{(1-\alpha-\beta) \mu^{f}}{\alpha}}\left(\frac{1}{\kappa}\right)^{\frac{\beta}{\alpha}}$.

Proof Lemma 1 and Lemma 2 show that adoption of home appliances and women's decision to work are equivalent $\left(a_{1}=1 \Leftrightarrow e_{t}=1\right)$ when $\varphi_{1} \leq \varphi \leq \varphi_{2}$. To link the adoption decision to the price of home appliances, it is thus enough to compare $U(1,1)$ and $U(0,0)$. Straightforward algebra reveals that $U(1,1) \geq U(0,0)$ if and only if $1+\varphi-\frac{p_{a t}}{\lambda_{m} w_{t}} \geq\left(\frac{1-\rho \eta}{1-t_{w}^{f}-\eta}\right)^{\frac{(1-\alpha-\beta) \mu f}{\alpha}}\left(\frac{1}{\kappa}\right)^{\frac{\beta}{\alpha}}$. Define $\phi(\varphi) \equiv 1+$ $\varphi-\left(\frac{1-\rho \eta}{1-t_{w}^{f}-\eta}\right)^{\frac{(1-\alpha-\beta) \mu}{\alpha}}\left(\frac{1}{\kappa}\right)^{\frac{\beta}{\alpha}}$. Then the previous inequality can be rewritten as $\phi(\varphi) \geq \frac{p_{a t}}{\lambda_{m} t w_{t}}$ or after rearranging $\lambda_{m} \geq$ $\frac{p_{a t}}{\phi(\varphi) w_{t}}$. Define $\hat{\lambda}_{m t} \equiv \frac{p_{a t}}{\phi(\varphi) w_{t}}$. We have the desired result: $e\left(\lambda_{m}, \frac{p_{a t}}{w_{t}}\right)=a\left(\lambda_{m}, \frac{p_{a t}}{w_{t}}\right)=1 \Leftrightarrow \lambda_{m} \geq \hat{\lambda}_{m t}$.

Given the relative price of home appliances, $\frac{p_{a t}}{w_{t}}$, and the ability gap between husband and wife $\varphi$, the previous proposition defines the marginal ability of the last households that buy home appliances. In all households with ability greater than $\hat{\lambda}_{m t}$ women work and home appliances are adopted. On the other hand, women in households with ability less than the threshold find it optimal to operate the labor-intensive technology and do not work.

According to Lemma 3, the demand for appliances in Eq. (10) is equal to:

$$
\begin{array}{r}
\mathcal{D}^{a}=\int_{0}^{+\infty} a\left(\lambda_{m}, \frac{p_{a t}}{w_{t}}\right) f\left(\lambda_{m}\right) d \lambda_{m}=\int_{\hat{\lambda}_{m t}}^{+\infty} f\left(\lambda_{m}\right) d \lambda_{m}= \\
1-F\left(\frac{p_{a t}}{w_{t} \phi(\varphi)}\right)
\end{array}
$$

where $F(\cdot)$ denotes the cumulative density function of men's market ability distribution. Women's labor supply is equal to:

$$
\begin{aligned}
\mathcal{S}^{f}=\varphi \int_{0}^{+\infty} & \lambda_{m} e\left(\lambda_{m}, \frac{p_{a t}}{w_{t}}\right) f\left(\lambda_{m}\right) d \lambda_{m} \\
& =\varphi \int_{\hat{\lambda}_{m t}}^{+\infty} \lambda_{m} f\left(\lambda_{m}\right) d \lambda_{m}
\end{aligned}
$$

where the second equality follows from the fact that the gender wage ratio $\varphi$ is constant across households.

Three different forces lead to a lower marginal ability threshold $\hat{\lambda}_{m t}=\frac{p_{a t}}{w_{t} \phi(\varphi)}$ implying an increase in labor force participation rate and greater adoption of home appliances. First, TFP growth in the appliances sector that pushes the price of home appliances down as in GSY; second, an increase in the gender ability ratio as in Jones et al. (2003). This paper proposes a third mechanism whereby rising wages affect the price of home appliances and thus the participation rate of married women.

In the Appendix we show that the first-order condition for firms in the home appliances sector in Eq. (7) can be re-written as:

$$
-\frac{w_{t} \phi(\varphi)}{f\left(\hat{\lambda}_{m t}\right)} y_{a t}+p_{a t}=\frac{w_{t}}{A_{a t}}
$$


Similarly, the free-entry condition in Eq. (8) is equal to:

$$
w_{m t} y_{a t}\left(\phi(\varphi) \hat{\lambda}_{m t}-\frac{1}{A_{a t}}\right)=\chi
$$

Eliminating $y_{a t}$ from Eqs. (16) and (17) let us link the market ability of the marginal household that adopts the home appliances to TFP in the goods and home appliances sector as well as the gender gap in ability:

$$
\left(\phi(\varphi) \hat{\lambda}_{m t}-\frac{1}{A_{a t}}\right)^{2} f\left(\hat{\lambda}_{m t}\right)=\frac{\chi \phi(\varphi)}{w_{m t}}
$$

We clarify the impact of technological progress in the market sector on women's employment and household appliances adoption decision in the next proposition.

Proposition 1 Everything else equal, a market wage threshold level exists, $\bar{w}_{m}>0$, such that Eq. (18) has no solution when $w_{m t}<\bar{w}_{m}$ and at least one solution that satisfies $\frac{\partial \hat{\lambda}_{m t}}{\partial w_{m t}} \leq 0$ when $w_{m t} \geq \bar{w}_{m}$.

Proof See the Appendix.

Proposition 1, which is the central result of the paper, states that the fraction of women joining the labor force increases as the market wage goes up since more households buy home appliances. The general equilibrium effect of market wage on women's decision to work is interesting because it contrasts with the predictions of existing neoclassical models of home production where women's employment decisions primarily depend on the earning gap between husband and wife (see Benhabib et al. 1991 or Jones et al. 2003). In these models, changes in the market wage level have no impact on women's employment decisions.

Due to our assumption of perfectly assortative matching between men and women's market ability, women who are married to high ability men are the first ones to adopt home appliances and work. While there is evidence that richer households adopted home appliances first (Day 1992) and that home appliances adoption had a positive impact on labor force participation of married women (Coen-Pirani et al. 2011), the data is less supportive that women in the upper deciles of the income distribution were the first ones to work. Schoonbroodt (2003) analyzes the relationship between labor force participation of married women and husband income score decile in the U.S. Census between 1900 and 1990. Interestingly, she finds that labor force participation is flat across income level. To obtain the flat relationship between women's labor force participation and husband income, Schoonbroodt (2003) suggests to add some source of heterogeneity that is itself income dependent to cancel out the effect of falling prices, but still keeping the increase in the participation rate. For example, if matching is less than perfect, then high ability women married to low ability men are more inclined to work, while the same women would not participate if married to a high ability (income) man.
Note that households do not adopt home appliances immediately but wait for relative prices to drop to more reasonable levels, a property also observed in GSY's model. When the market wage is below the threshold $\bar{w}_{m}$, households choose to operate the labor-intensive technology for home production because the cost of home appliances is very high relative to the market wage. No home appliances are produced and output in the appliances sector is equal to zero. As technological progress in the market sector unfolds, the price of home appliances gradually declines relative to the market wage since $\frac{p_{a t}}{w_{t}}=\phi(\varphi) \hat{\lambda}_{m t}$ and $\frac{\partial \hat{\lambda}_{m t}}{\partial w_{m t}} \leq 0$. As a result, a positive fraction of the population, $1-F\left(\hat{\lambda}_{m t}\right)$, can afford to adopt the new technology and this fraction increases over time.

The next proposition characterizes the general equilibrium effects of rising wages on the price of home appliances.

Proposition 2 A threshold for market ability $\bar{\lambda}>0$ exists such that:

1. $\frac{\partial p_{a t}}{\partial w_{m t}}<0$ when $\hat{\lambda}_{m t}>\bar{\lambda}$,

2. $\frac{\partial p_{a t}}{\partial w_{m t}} \geq 0$ when $\hat{\lambda}_{m t} \leq \bar{\lambda}$.

Proof See the Appendix.

The previous proposition shows that the price of appliances initially declines when the home appliances adoption rate as measured by $\hat{\lambda}_{m t}$ is low. This happens because with profits opportunity looming large, many new firms enter the market and the depressing effects of a greater supply outweigh the outward shift in the demand for home appliances due to higher household wages. After a while, house appliances adoption becomes widespread and the price of home appliances increases with wages as the income effect dominates.

The next proposition shows that the threshold ability $\hat{\lambda}_{m t}$ decreases with the home productivity level $A_{a t}$ and the gender wage ratio $\varphi$. These results are expected since there is a direct inverse relationship between home appliances prices and total factor productivity in the sector. A narrowing of the gender wage gap implies that more women join the labor force, although lower discrimination levels have less of an impact on women's labor supply compared to Jones et al. (2003) since accumulating human capital is not an option in our model.

Proposition 3 Everything else equal, a home productivity threshold level exists, $\bar{A}_{a}$, such that Eq. (18) has no solution when $A_{a t}<\bar{A}_{a}$ and at least one solution that satisfies $\frac{\partial \hat{\lambda}_{m t}}{\partial A_{a t}} \leq$ 0 when $A_{a t} \geq \bar{A}_{a}$. In addition, Eq. (18) has at least one solution that satisfies $\frac{\partial \hat{\lambda}_{m t}}{\partial \varphi} \leq 0$.

Proof See the Appendix. 


\section{A numerical example}

In this section, we propose a numerical analysis of Eq. (18) to illustrate how rising household wages affected the price of home appliances and labor force participation decision of married women between 1960 and 1970. One reason we chose this time frame, rather than the period between 1900 and 1985 examined by GSY, is the study by Coen-Pirani et al. (2010) that finds strong empirical support in the 1960 and 1970 U.S. Census micro-data for the mechanism proposed by GSY.

Based on a sample including white, U.S.-born, married women of prime working age (18-55 years old), with nonmissing information on state of residence and appliance ownership, not living in group quarters and with working husbands, Coen-Pirani et al. (2010) find that labor force participation rate for married women increased from $33 \%$ in 1960 to $43 \%$ in $1970 .{ }^{12}$ For the same sample, the median real household income, expressed in 2000 dollars, increased from $\$ 32,768$ in 1960 to $\$ 39,384$ in 1970.

We assume that adults are endowed with a total of 112 hours per week (excluding sleep) to be divided between work, house chores, and leisure. The number of hours spent on house chores decreased from 26 in 1960 to 20 were in 1970 (GSY). ${ }^{13}$ McGrattan and Rogerson (2004) find that women who work full-time spend $36 \mathrm{~h}$ on the job. As a result, we have $t_{w}^{f}=\frac{36}{112}=0.32, \eta=\frac{20}{112}=0.18$, and $\rho=\frac{26}{20}=1.3$. The per-capita stock of appliances was equal to $\$ 96.7$ in 1960 and increased to $\$ 177.5$ in $1970 .{ }^{14}$ As a result, we set $\kappa=\frac{\$ 177.5}{\$ 96.7}=1.84$.

We assume that men's ability distribution follow a log-normal distribution with mean $\mu$ and standard deviation $\sigma$. That is, $f\left(\lambda_{m}\right)=\frac{1}{\lambda_{m} \sqrt{2 \pi} \sigma} e^{-\frac{\left(\ln \left(\lambda_{m}\right)-\mu\right)^{2}}{2 \sigma^{2}}}$ and $F\left(\lambda_{m}\right)=$ $\int_{-\infty}^{\lambda_{m}} f(u) d u$. We follow Greenwood et al. (2003) who estimates the standard deviation of men's income distribution within a dynamic general equilibrium model and finds that $\sigma=0.9$. We choose his value for the standard deviation and normalize the mean of men's ability distribution to be equal

\footnotetext{
${ }^{12}$ Coen-Pirani et al. (2010) also find that hours worked by married women did not change appreciably from 1960 to 1970, while other measures of labor force participation such as full-time employment (share of married women working at least 35 hours in the past week), and year-round employment (share of married women working at least 48 weeks in the past year) also indicate a large increase in female labor supply during the 1960's. These results confirm that the main changes in labor supply for married women occurred at the extensive margin, not the intensive margin.

${ }^{13}$ Using data from the Panel Study on Income Dynamics, Roberts and Rupert (1995) report that between 1976 and 1988 the time spent on housework by a working wife continues to fall from $20.2 \mathrm{~h}$ per week to $15.9 \mathrm{~h}$. The time spent by a non-working wife dropped very slightly from 34.0 to $32.2 \mathrm{~h}$ per week.

${ }^{14}$ Source: U.S. Census: Fixed Reproducible Tangible Wealth in the United States, 1925-2010 - Table 707.
}

to 100 , which implies that $\mu=-\frac{0.9^{2}}{2}+\ln (100)=4.2$. According to Coen-Pirani et al. (2010), the labor force participation rate of women in 1960 is $33 \%$. As a result the threshold ability of the marginal household that buys home appliances is equal to $\hat{\lambda}_{1960}=F^{-1}(0.67 ; 4.2,0.9)=99.07$.

We fix $\varphi_{1960}=0.6$ as this is the value for the women-tomen wage ratio in 1960 in the historical income table P-36 of the Census bureau for men and women who work full-time all-year around.

For preference parameters, we take the same values as in GSY with $\alpha=\beta=\frac{1}{3}$ and we assume equal bargaining power between men and women and thus fix $\mu^{f}=0.5$. Our parameter values imply $\phi\left(\varphi_{1960}\right)=0.6478 .{ }^{15}$

We use Eq. (7) to pin down total factor productivity in the home appliances sector in 1960. After rearranging, we get $A_{a, 1960}=\frac{w_{1960} / p_{a, 1960}}{1+\epsilon_{p a}}$ where $\epsilon_{p_{a}}$ is the price elasticity for home appliances. We choose a value of -0.3 for $\epsilon_{p_{a}}$ based on Dale and Fujita (2008) who find that the price elasticity for home appliances varies between -0.42 for dishwasher to -0.37 for refrigerators and -0.14 for cloth dryers. The average cost of a refrigerator in 1960 was $\$ 289$ which expressed in 2000 dollars equals $\$ 1,356$. As a result, total factor productivity in the home sector in 1960 is equal to $A_{a, 1960}=34.5$.

In our first counterfactual experiment, we assess the impact of TFP growth in the market good sector on the price of home appliances and women's labor supply, independently of TFP growth in the appliances sector and changes in the gender wage ratio. We ask: If market wages grew from $\$ 32,768$ in 1960 to $\$ 39,384$ in 1970 and there was no growth in total factor productivity in the home appliances sector and no change in the gender wage ratio, what would the labor force participation rate of married women be equal to in 1970 ? By how much would the price of home appliances decline between 1960 and 1970 ?

The answer to the above question is obtained by solving for $\hat{\lambda}_{1970}$ in the following condition which is derived from

\footnotetext{
${ }^{15}$ Throughout the paper, we worked with the assumption that men and women have equal bargaining power within the household, a heroic assumption for sure both in the unitary framework or the collective bargaining one of Chiappori et al. (2011). A legitimate and open research question therefore is how an asymmetric bargaining power affect women's participation decision as well as home appliances decision. For example, it would make sense that the rate of adoption of home appliances increases, reflecting a heavier weight on women's utility. In our model however, we find that although changes in woman's bargaining power affect the threshold $\phi(\varphi)$, a higher value of $\mu^{f}$ does not alter the qualitative results as stated in Proposition 1 to 3. In addition, given our choice of functional forms for preferences and technology, a higher value for $\mu^{f}$ has no quantitative effects on changes in labor supply as summarized in Table 1 below.
} 
Eq. (18):

$$
\left(\frac{\phi\left(\varphi_{1960}\right) \hat{\lambda}_{m, 1970}-\frac{1}{A_{a, 1960}}}{\phi\left(\varphi_{1960}\right) \hat{\lambda}_{m, 1960}-\frac{1}{A_{a, 1960}}}\right)^{2} \frac{f\left(\hat{\lambda}_{m, 1970}\right)}{f\left(\hat{\lambda}_{m, 1960}\right)}=\frac{w_{m, 1960}}{w_{m, 1970}}
$$

Experiment results are summarized in Table 1 below. We find that the threshold market ability decreased to $\hat{\lambda}_{1970}=$ 88.2 which implies labor force market participation for married women increased by 4.8 percentage points (from $33 \%$ in 1960 to $37.8 \%$ in 1970) compared to 10 percentage points in the data (from $33 \%$ in 1960 to $43 \%$ in 1970 - Coen-Pirani et al. 2011). Over the same period of time, the ratio between the home appliances price and the median household wage declined by $11 \%$ as $\frac{\hat{\lambda}_{1970}}{\hat{\lambda}_{1960}}=0.89$.

Second, we assess the impact of TFP growth in the home appliances sector on women's labor supply, independently of TFP growth in the market good sector and changes in the gender wage ratio. Bar and Leukhina (2011) analyze data from the National Income and Product Accounts on kitchen appliances which does not include TVs and VCRs. ${ }^{16}$ They find that the price of home appliances declined by $26 \%$ relative to market wages between 1960 and 1970 which implies a decline in the price of home appliances of $9 \%$ relative to the numeraire for the entire period or $0.87 \%$ when compounded on an annual basis. In our second counterfactual experiment, we ask: If TFP in the home appliances sector grew by $9 \%$ between 1960 and 1970 and there is no growth in total factor productivity in the market goods sector and no change in the gender wage ratio, what would the labor force participation rate of married women be equal to in 1970 ?

The answer to the above question is obtained by solving for $\hat{\lambda}_{1970}$ in the following condition:

$$
\left(\frac{\phi\left(\varphi_{1960}\right) \hat{\lambda}_{m, 1970}-\frac{1}{A_{a, 1970}}}{\phi\left(\varphi_{1960}\right) \hat{\lambda}_{m, 1960}-\frac{1}{A_{a, 1960}}}\right)^{2} \frac{f\left(\hat{\lambda}_{m, 1970}\right)}{f\left(\hat{\lambda}_{m, 1960}\right)}=1
$$

We find that the threshold market ability is virtually unchanged to $\hat{\lambda}_{1970}=98.5$ which implies labor force market participation for married women and increases by 0.3 percentage points, from $33 \%$ in 1960 to $33.3 \%$ in 1970 .

The gender wage ratio declined slightly from 0.6 to 0.58 between 1960 and 1970 (U.S. Census - Table P-36: Historical income for men and women). We do not perform a counterfactual analysis of the impact of changes in the gender wage ratio since our model mechanism would predict a decline in

\footnotetext{
${ }^{16}$ By 1960 many kitchen appliances were widely adopted across the U.S. households. For this reason and because the price index in Bar and Leukhina (2011) does not include TV's and VCRs, the rate of decline for the home appliances prices in Bar and Leukhina (2011) is much smaller compared to the one in Gordon (1990). Vandenbroucke (2009) conjectures that a decline in the price of goods which complements leisure time, such as VCR and TVs, leads to a fall in labor market supply.
}

Table 1 Change in women's labor force participation, 1960-1970

\begin{tabular}{llll}
\hline & 1960 & 1970 & $\begin{array}{l}\text { Change } \\
\text { (perc. pts) }\end{array}$ \\
\hline $\begin{array}{l}\text { Data (Coen-Pirani 2011): } \\
\begin{array}{l}\text { Model: } \\
\text { Market Wages alone: }\end{array}\end{array}$ & 0.33 & 0.43 & +10 \\
$\begin{array}{l}\text { TFP home appliances } \\
\text { alone: }\end{array}$ & 0.33 & 0.378 & +4.8 \\
$\begin{array}{l}\text { All (excl. changes in } \\
\text { gender wage ratio): }\end{array}$ & 0.33 & 0.333 & +0.3 \\
\hline
\end{tabular}

labor force participation of married women between 1960 and 1970 which is not observed in the data.

Finally, we consider the impact of TFP growth in both sectors altogether with no changes in the gender wage ratio. We ask: If market wages grew from \$32,768 in 1960 to $\$ 39,384$ in 1970 while TFP in the home appliances sector grew by $9 \%$, and the gender wage ratio is unchanged, what would the labor force participation rate of married women be equal to in 1970 ? We find that the threshold market ability decreased to $\hat{\lambda}_{1970}=87.4$ which implies labor force market participation for married women increased by 5.2 percentage points, from $33 \%$ in 1960 to $38.2 \%$ in $1970 .{ }^{17}$

In summary, we find that the mechanisms presented in this paper linking changes in the market wage to the adoption of home appliances and women's labor force participation decisions are quantitatively important. Increases in market wages taken alone account for slightly less than half of the increase in labor force participation of married women between 1960 and 1970. Quantitatively, technological progress in the home appliances sector play a lesser role compared to GSY. Finally, Proposition 3 shows that women's labor force participation increases with the gender wage ratio, which is also observed in historical data. For the period we considered, however, the gender wage ratio declined which would place our model's predictions at odds with the observed change in labor force participation of married women between 1960 and 1970. In addition, the quantitative impact of changes in the gender wage ratio on women's labor force participation would be more muted compared to Jones et al. (2003) because agents cannot decide to accumulate human capital in our model.

\section{Concluding remarks}

Recent research has linked the adoption of productivityenhancing technology at home (home appliances) to the rise in employment of married women in the twentieth century. Here we proposed a simple model of household decisions to show that once the price of home appliances is allowed to be determined endogenously, a new mechanism for women's

\footnotetext{
${ }^{17}$ If we include decline in the gender wage ratio from 0.6 to 0.58 , we find that labor force participation of married women increased by only 3.6 percentage points from $33 \%$ in 1960 to $36.6 \%$ in 1970 .
} 
decision to join the labor force emerges. Our main result is that total factor productivity growth rates in all sectors as well as a narrowing gender wage gap contributed to women joining the labor force by making home appliances more affordable. A numerical example suggests that rising household wages account for half of the increase in labor force participation of married women between 1960 and 1970 .

We see two possible avenues for future research on the topic of household appliances and female labor supply. First, we assumed that husbands and wives are perfectly matched with respect to their market ability and that the gender wage ratio is constant across households. Although assortative matching in ability and education especially is welldocumented (Browning et al. 2011), relaxing these two assumptions would make the interaction between women's labor supply and the home appliances adoption decision richer. For example, if some men with high market ability could marry women with low market ability (or women who decide not to work for other reasons), then it might be possible that rich households adopt home appliances first without necessary implying that women married to rich men would join the labor force.

Another possible extension of our work would be to incorporate our mechanism into a full-blown dynamic model and evaluate how much of the increase in labor force participation of married women in the U.S. during the twentieth century can be accounted for by rising household wages. We leave these two important projects for future research.

\section{Kurzfassung}

Dieser Artikel leistet einen Beitrag zu laufenden wirtschaftlichen Untersuchungen, welche die Gründe für den Anstieg der Erwerbsbeteiligung verheirateter Frauen in den USA (und in anderen Ländern) im 20. Jahrhundert erforschen. Eine bedeutende Erklärung von Greenwood et al. (2005) (später GSY) betont die Verwendung von Investitionsgütern in Haushalten (Haushaltsgeräte), was einen bedeutenden Zeitgewinn bedeutet und verheirateten Frauen eine Berufstätigkeit gestattet. Familien stehen dann vor der gemeinsamen Entscheidung, ob sie Haushaltsgeräte zum momentanen Zeitpunkt anschaffen oder auf einen geringeren Preis warten. Zusätzlich muss der Haushaltsvorstand entscheiden, ob die Frau auf dem Arbeitsmarkt tätig werden soll oder nicht.

In diesem Artikel schlagen wir ein allgemeines Gleichgewichtsmodell des Haushalts vor, in welchem der Übertragungsmechanismus zwischen Haushaltsgeräten und dem Angebot an weiblichen Arbeitskräften mit einer wichtigen Ausnahme dem in GSY entspricht. Wir modellieren explizit die Preis- und Produktionsentscheidungen der Unternehmen im Haushaltsgerätesektor sowie Branchendynamiken. Demzufolge wird die Schlüsselvariable in GSY - der Preis von
Haushaltsgeräten - endogen von den Gesetzen von Angebot und Nachfrage bestimmt und nicht exogen von außerhalb des Modells. Wir nutzen diesen neuen Rahmen, um die allgemeinen Ausgleichseffekte steigender Haushaltseinkommen auf die Preise von Haushaltsgeräten und letztlich das Angebot an weiblichen Arbeitskräften zu bestimmen.

Die folgenden Mechanismen bestimmen den Gleichgewichtswert von Haushaltsgerätepreisen: Einerseits verschiebt sich angesichts unserer Auswahl an Dienstfunktionen, wo Haushaltsgeräte ein normales Gut sind, die Nachfrage nach Haushaltsgeräten als Folge eines Anstiegs des Haushaltseinkommens nach außen, was zu gestiegenen Preisen für Haushaltsgeräte führt. Andererseits drücken zwei Kräfte die Preise für Haushaltsgeräte. Zunächst nehmen wir wie in GSY an, dass der gesamte Faktor Produktivität im Haushaltsgerätesektor in einem exogen gegebenen Verhältnis ansteigt. Im zweiten Fall nehmen wir an, dass der Wettbewerb im Haushaltsgerätesektor unvollkommen ist und modellieren die strategische Interaktion zwischen Firmen als Cournot-Oligopol. In beiden Fällen ziehen kurzfristige Gewinnmöglichkeiten durch ein Marktwachstum auf dem Haushaltsgerätesektor neue Marktteilnehmer an, was das Angebot nach außen verschiebt und den Preis für Haushaltsgeräte weiter drückt.

Unser wichtigstes Ergebnis ist, dass das Verhältnis zwischen dem Preis von Haushaltsgeräten und Haushaltseinkommen nach einem Anstieg des Lohnniveaus sinkt, was wiederum zu einer gestiegenen Verwendung von Haushaltsgeräten und Erwerbsbeteiligung verheirateter Frauen führt. Als solches entsteht ein neuer Mechanismus, in welchem der gesamte Faktor Produktivität in allen wirtschaftlichen Bereichen die Entscheidung von Frauen zur Erwerbstätigkeit beeinflusst. Dieses neue Ergebnis ist interessant, da andere an anderer Stelle gezeigt haben, dass die Entscheidung von Frauen über eine Erwerbstätigkeit von der Einkommenslücke zwischen Mann und Frau abhängt, jedoch vom technischen Fortschritt und seinen Auswirkungen auf das Haushaltseinkommensniveau unbeeinflusst bleibt (Benhabib et al. 1991 oder Jones et al. 2003). In diesem Artikel entscheiden sich verheiratete Frauen jedoch zur Erwerbstätigkeit, weil steigende Löhne indirekt Haushaltsgeräte erschwinglicher machen, obwohl die Einkommenslücke zu ihren Ehemännern unverändert ist.

Modellsimulationen zeigen, dass die in diesem Artikel untersuchten Mechanismen Veränderungen des Marktlohns mit der Verwendung von Haushaltsgeräten in Verbindung bringen und Entscheidungen von Frauen über eine Erwerbstätigkeit quantitativ wichtig sind. Allein betrachtet sind Anstiege der Marktlöhne für knapp die Hälfte des Anstiegs der Erwerbsbeteiligung verheirateter Frauen zwischen 1960 und 1970 verantwortlich. Im Vergleich zu GSY spielt der technische Fortschritt quantitativ eine geringere Rolle im Hausgerätesektor. 
Table 2 4-Firm concentration ratio and Herfindahl-Hirshman index by year, 1960-1970

\begin{tabular}{ll}
\hline Appliances type & $\begin{array}{l}\text { Concentration ratio } \\
\text { (4 largest firms) }\end{array}$ \\
\hline Household vacuum cleaner & \\
$\quad$ (SIC: 3635) & \\
Year - 1963: & $81 \%$ \\
1966: & 78 \\
1967: & 76 \\
1970: & 79 \\
Cooking appliances (SIC: 3631) & \\
1963: & $51 \%$ \\
1966: & 54 \\
1967: & 56 \\
1970: & 61 \\
Refrigerator and home freezer (SIC: & \\
3632) & \\
1963: & $74 \%$ \\
1966: & 72 \\
1967: & 73 \\
1970: & 82 \\
Laundry equipment (SIC: 3633) & \\
1963: & $78 \%$ \\
1966: & 79 \\
1967: & 78 \\
1970: & 83 \\
\hline
\end{tabular}

Abschließend sehen wir zwei Richtungen für künftige Untersuchungen. Der Einfachheit halber geht die Analyse in diesem Artikel davon aus, dass Männer und Frauen im Hinblick auf ihr Marktpotential perfekt zusammenpassen und dass das Geschlechter-Lohn-Verhältnis über Haushalte hinweg konstant ist. Obwohl assortative Paarung nach Fähigkeiten, und insbesondere Bildung, gut dokumentiert ist (Browning et al. 2011), würde eine Lockerung dieser beiden Annahmen die Interaktion zwischen dem Angebot an weiblichen Arbeitskräften und der Entscheidung über eine Verwendung von Haushaltsgeräten bereichern. Wenn beispielsweise manche Männer mit großem Marktpotenzial Frauen mit geringem Marktpotenzial heiraten würden (oder Frauen, die aus anderen Gründen nicht arbeiten), dann könnte es möglich sein, dass reiche Haushalte Haushaltsgeräte zuerst verwenden, ohne dass dies zu bedeuten hat, dass Frauen erwerbstätig sein müssen. Eine weitere mögliche Ergänzung unserer Arbeit wäre die Einbeziehung unseres Mechanismus in ein komplettes dynamisches Modell und die Bewertung, welcher Anteil des Anstiegs der Erwerbsbeteiligung verheirateter Frauen in den USA im 20. Jahrhundert in gestiegenen Haushaltseinkommen begründet liegt.

\section{Appendix}

Concentration ratios for the home appliances sector

In Table 2, we present the 4-firm concentration ratio for four home appliances between 1960 and 1970: household vacuum cleaner (SIC: 3635), cooking appliances (SIC: 3631), refrigerator and home freezer (SIC: 3632), and automatic washing machines (SIC: 3633). Data come from manufacturing reports published by the Census Bureau in Concentration Ratios in Manufacturing between 1942 and 1997. The 4-firm concentration ratio is defined as the percentage of market output generated by the four largest firms in the industry. Concentration ratios range from 48.3 for cooking appliances to 93.7 for laundry equipment. Although there are no strict cutoffs or guidelines, an industry is considered perfectly competitive when the 4 -firm concentration ratio is less than $15 \%$, monopolistic competition when concentration is less than $40 \%$, and oligopolistic when concentration is greater than $40 \%$. Concentration ratios suggest that competition in the home appliances sector is not perfectly competitive between 1960 and 1970.

Eq. 16

We first show that the derivative of the demand for home appliances is equal to:

$$
p_{a t}^{\prime}\left(Y_{a t}\right)=-\frac{w_{t} \phi(\varphi)}{f\left(\hat{\lambda}_{m t}\right)}
$$

Proof According to the equilibrium condition in the home appliances sector as well as Eq. (14), the equilibrium quantity of home appliances is equal to $Y_{a t}=1-F\left(\frac{p_{a t}}{w_{t} \phi(\varphi)}\right)$. Differentiate with respect to $Y_{a t}$, we get: $1=-f\left(\frac{p_{a t}}{w_{t} \phi(\varphi)}\right) \frac{p_{a t}^{\prime}\left(Y_{a t}\right)}{w_{t} \phi(\varphi)}=$ $-f\left(\hat{\lambda}_{m t}\right) \frac{p_{a t}^{\prime}\left(Y_{a t}\right)}{w_{t} \phi(\varphi)}$. Rearranging, we obtain the desired result that $p_{a t}^{\prime}\left(Y_{a t}\right)=-\frac{w_{t} \phi(\varphi)}{f\left(\hat{\lambda}_{m t}\right)}$.

Recall that Eq. (7) is given by:

$$
p_{a t}^{\prime}\left(Y_{a t}\right) y_{a, t}+p_{a t}\left(Y_{a t}\right)=\frac{w_{t}}{A_{a t}}
$$

From Eq. (21), we can write Eq. (7) as:

$$
-\frac{w_{t} \phi(\varphi)}{f\left(\hat{\lambda}_{m t}\right)} y_{a, t}+p_{a t}=\frac{w_{t}}{A_{a t}}
$$

which is Eq. (16).

Proof of proposition 1

Proof We need to calculate the sign of the following derivative, $\frac{\partial \lambda_{m t}}{\partial w_{m t}}$. Recall that Eq. (18) is equal to:

$$
\left(\phi(\varphi) \hat{\lambda}_{m t}-\frac{1}{A_{a t}}\right)^{2} f\left(\hat{\lambda}_{m t}\right)=\frac{\chi \phi(\varphi)}{w_{m t}}
$$


Define $g\left(\hat{\lambda}_{m t}\right)=\left(A_{a t} \phi(\varphi) \hat{\lambda}_{m t}-1\right)^{2} f\left(\hat{\lambda}_{m t}\right)$. Taking logarithm, we get:

$$
\ln \left(g\left(\hat{\lambda}_{m t}\right)\right)=2 \ln \left(A_{a t} \phi(\varphi) \hat{\lambda}_{m t}-1\right)+\ln \left(f\left(\hat{\lambda}_{m t}\right)\right)
$$

Differentiating with respect to $w_{m t}$ yields:

$$
\frac{g^{\prime}\left(\hat{\lambda}_{m t}\right)}{g\left(\hat{\lambda}_{m t}\right)}=\frac{2 A_{a t} \phi(\varphi)}{A_{a t} \phi(\varphi) \hat{\lambda}_{m t}-1}+\frac{f^{\prime}\left(\hat{\lambda}_{m t}\right)}{f\left(\hat{\lambda}_{m t}\right)}
$$

Given that the probability density function of $\hat{\lambda}_{m t}$ is equal to $f\left(\lambda_{m}\right)=\frac{1}{\lambda_{m} \sqrt{2 \pi} \sigma} e^{-\frac{\left(\ln \left(\lambda_{m}\right)-\mu\right)^{2}}{2 \sigma^{2}}}$, it can be shown that:

$$
\frac{f^{\prime}\left(\hat{\lambda}_{m t}\right)}{f\left(\hat{\lambda}_{m t}\right)}=-\frac{1}{\hat{\lambda}_{m t}}\left(1+\frac{\ln \left(\hat{\lambda}_{m t}\right)-\mu}{\sigma^{2}}\right)
$$

As a result, Eq. (26) is equal to:

$$
\frac{g^{\prime}\left(\hat{\lambda}_{m t}\right)}{g\left(\hat{\lambda}_{m t}\right)}=\frac{2 A_{a t} \phi(\varphi)}{A_{a t} \phi(\varphi) \hat{\lambda}_{m t}-1}-\frac{1}{\hat{\lambda}_{m t}}\left(1+\frac{\ln \left(\hat{\lambda}_{m t}\right)-\mu}{\sigma^{2}}\right)
$$

Or after rearranging:

$\frac{g^{\prime}\left(\hat{\lambda}_{m t}\right)}{g\left(\hat{\lambda}_{m t}\right)}=\frac{1}{\hat{\lambda}_{m t}}+\frac{2}{\hat{\lambda}_{m t}\left(A_{a t} \phi(\varphi) \hat{\lambda}_{m t}-1\right)}-\frac{1}{\hat{\lambda}_{m t}} \frac{\ln \left(\hat{\lambda}_{m t}\right)-\mu}{\sigma^{2}}$

Collecting terms and rearranging once more yields:

$\frac{\hat{\lambda}_{m t} g^{\prime}\left(\hat{\lambda}_{m t}\right)}{g\left(\hat{\lambda}_{m t}\right)}=1+\frac{2}{A_{a t} \phi(\varphi) \hat{\lambda}_{m t}-1}-\frac{\ln \left(\hat{\lambda}_{m t}\right)-\mu}{\sigma^{2}}$

In other words, the sign of $\frac{\partial \hat{\lambda}_{m t}}{\partial w_{m t}}$ depends on the sign of the following expression:

$$
h\left(\hat{\lambda}_{m t}\right) \equiv 1+\frac{2}{A_{a t} \phi(\varphi) \hat{\lambda}_{m t}-1}-\frac{\ln \left(\hat{\lambda}_{m t}\right)-\mu}{\sigma^{2}}
$$

The function $h$ is continuously differentiable on the inter$\operatorname{val}\left(\frac{1}{A_{a t} \phi(\varphi)},+\infty\right)$ and is monotone decreasing with $h^{\prime}\left(\hat{\lambda}_{m t}\right)<$ 0 . In addition, since $\lim _{\hat{\lambda}_{m t} \rightarrow{\frac{1}{A_{a t} \phi(\varphi)}}^{+}} h\left(\hat{\lambda}_{m t}\right)=+\infty$ and

$\lim h\left(\hat{\lambda}_{m t}\right)=-\infty$, the intermediate value theorem of $\hat{\lambda}_{m t} \rightarrow+\infty$

calculus guarantees that the equation $h\left(\hat{\lambda}_{m t}\right)=0$ has a unique solution that we call $\hat{\lambda}_{m 0}$.

Since $h$ is decreasing, we have $h\left(\hat{\lambda}_{m t}\right)>0$ when $\frac{1}{A_{a t} \phi(\varphi)}<$ $\hat{\lambda}_{m t}<\hat{\lambda}_{m 0}$ and $h\left(\hat{\lambda}_{m t}\right) \leq 0$ when $\hat{\lambda}_{m t} \geq \hat{\lambda}_{m 0}$. As a result, we have $g^{\prime}\left(\hat{\lambda}_{m t}\right)>0$ when $\frac{1}{A_{a t} \phi(\varphi)}<\hat{\lambda}_{m t}<\hat{\lambda}_{m 0}$ and $g^{\prime}\left(\hat{\lambda}_{m t}\right)<0$ when $\hat{\lambda}_{m t}>\hat{\lambda}_{m 0}$. This implies that the function $g$ is increasing for $\frac{1}{A_{a t} \phi(\varphi)}<\hat{\lambda}_{m t}<\hat{\lambda}_{m 0}$, decreasing for $\hat{\lambda}_{m t}>\hat{\lambda}_{m 0}$, and reaches its maximum at $\hat{\lambda}_{m t}=\hat{\lambda}_{m 0}$.
We define the threshold $\bar{A}_{m}$ as:

$$
\bar{A}_{m}=\frac{\chi \phi(\varphi)}{\left(\phi(\varphi) \hat{\lambda}_{m 0}-\frac{1}{A_{a t}}\right)^{2} f\left(\hat{\lambda}_{m 0}\right)}
$$

When $0<A_{m t}<\bar{A}_{m}$, we have $\frac{\phi(\varphi) \chi}{A_{m t}}>\left(\phi(\varphi) \hat{\lambda}_{m 0}-\right.$ $\left.\frac{1}{A_{a t}}\right)^{2} f\left(\hat{\lambda}_{m 0}\right)$. Hence there is no $\hat{\lambda}_{m t}$ such that Eq. (18) is satisfied. On the other hand, since the function $g$ has a $\cap$ shape, Eq. (18) has at least one solution when $A_{m t} \geq \bar{A}_{m}$ which satisfies $\hat{\lambda}_{m t} \leq \hat{\lambda}_{m 0}$.

We can now show the main result of the theorem that $\frac{\partial \lambda_{m t}}{\partial w_{m t}} \leq 0$. Taking logarithm of Eq. (18) yields:

$$
\begin{aligned}
2 \ln \left(A_{a t} \phi(\varphi) \hat{\lambda}_{m t}-1\right)+\ln \left(f\left(\hat{\lambda}_{m t}\right)\right)= & -\ln \left(w_{m t}\right)+ \\
& \ln \left(A_{a t}^{2} \chi \phi(\varphi)\right)
\end{aligned}
$$

Differentiating with respect to $w_{m t}$ yields:

$$
\frac{\partial \lambda_{m t}}{\partial w_{m t}} \frac{g^{\prime}\left(\hat{\lambda}_{m t}\right)}{g\left(\hat{\lambda}_{m t}\right)}=-\frac{1}{w_{m t}}
$$

Since we showed that $g^{\prime}\left(\hat{\lambda}_{m t}\right) \geq 0$ when $\hat{\lambda}_{m t} \leq \hat{\lambda}_{m 0}$, it follows that Eq. (18) has at least one solution which satisfies $\frac{\partial \lambda_{m t}}{\partial w_{m t}} \leq 0$ when $\hat{\lambda}_{m t} \leq \hat{\lambda}_{m 0}$.

\section{Proof of proposition 2}

Following the notation introduced in Lemma 3, the price of home appliances is equal to $p_{a t}=w_{m t} \phi(\varphi) \hat{\lambda}_{m t}$. Taking logarithm and differentiating the price of home appliances with respect to $w_{m t}$ gives:

$$
\frac{1}{p_{a t}} \frac{\partial p_{a t}}{\partial w_{m t}}=\frac{1}{w_{m t}}+\frac{1}{\hat{\lambda}_{m t}} \frac{\partial \hat{\lambda}_{m t}}{\partial w_{m t}}
$$

According to Eq. (34), (30), and (31), we have:

$$
\frac{\partial \lambda_{m t}}{\partial w_{m t}}=-\frac{1}{w_{m t}} \frac{g\left(\hat{\lambda}_{m t}\right)}{g^{\prime}\left(\hat{\lambda}_{m t}\right)}=-\frac{1}{w_{m t}} \frac{\hat{\lambda}_{m t}}{h\left(\hat{\lambda}_{m t}\right)}
$$

As a result, the first derivative of the price of home appliances is equal to:

$$
\frac{1}{p_{a t}} \frac{\partial p_{a t}}{\partial w_{m t}}=\frac{1}{w_{m t}}\left(1-\frac{1}{h\left(\hat{\lambda}_{m t}\right)}\right)=\frac{1}{w_{m t} h\left(\hat{\lambda}_{m t}\right)}\left(h\left(\hat{\lambda}_{m t}\right)-1\right)
$$

We know from the proof of Proposition 1 that $h\left(\hat{\lambda}_{m t}\right)>0$ when $\hat{\lambda}_{m t}<\hat{\lambda}_{m 0}$. As a result, the sign of the derivative $\frac{\partial p_{a t}}{\partial w_{m t}}$ depends on the sign of $h\left(\hat{\lambda}_{m t}\right)-1$.

The threshold $\hat{\lambda}_{m 0}$ was defined as $h\left(\hat{\lambda}_{m 0}\right)=0$. Since the function $h$ is decreasing and continuous, it must be the case that $h\left(\hat{\lambda}_{m t}\right)<1$ in a neighborhood of $\hat{\lambda}_{m 0}$ which implies that $\frac{\partial p_{a t}}{\partial w_{m t}}<0$ in a neighborhood of $\hat{\lambda}_{m 0}$. 
We also know from the proof of Proposition 1 that $\lim _{\frac{1}{A_{A t} \phi(\varphi)}} h\left(\hat{\lambda}_{m t}\right)=+\infty$. In other words, by continuity, there must exist a threshold $\bar{\lambda}$ such that $h\left(\hat{\lambda}_{m t}\right) \geq 1$ when $\hat{\lambda}_{m t} \leq \bar{\lambda}$ which implies that $\frac{\partial p_{a t}}{\partial w_{m t}} \geq 0$ when $\hat{\lambda}_{m t} \leq \bar{\lambda}$.

In summary we have shown the following result which is Proposition 2: There exists a threshold $\bar{\lambda}>0$ such that:

1. $\frac{\partial p_{a t}}{\partial w_{m t}}<0$ when $\hat{\lambda}_{m t}>\bar{\lambda}$,

2. $\frac{\partial p_{a t}}{\partial w_{m t}} \geq 0$ when $\hat{\lambda}_{m t} \leq \bar{\lambda}$.

Proof of proposition 3

Proof Eq. (18) can be written as:

$$
\left(A_{a t} \phi(\varphi) \hat{\lambda}_{m t}-1\right)^{2} f\left(\hat{\lambda}_{m t}\right)=\frac{\chi \phi(\varphi) A_{a t}^{2}}{w_{m t}}
$$

Taking logarithm and differentiating the previous equation with respect to $A_{a t}$ yields:

$$
\frac{\partial \hat{\lambda}_{m t}}{\partial A_{a t}} \frac{g^{\prime}\left(\hat{\lambda}_{m t}\right)}{g\left(\hat{\lambda}_{m t}\right)}=\frac{2}{A_{a t}}-\frac{2}{A_{a t}-\frac{1}{\phi(\varphi) \hat{\lambda}_{m t}}}
$$

where the function $g$ is defined in Eq. (25).

In Proposition 1, we showed that that $g^{\prime}\left(\hat{\lambda}_{m t}\right) \geq 0$ when $\hat{\lambda}_{m t} \leq \hat{\lambda}_{m 0}$. Since the right-hand side of Eq. (39) is negative, it follows that Eq. (18) has at least one solution which satisfies $\frac{\partial \hat{\lambda}_{m t}}{\partial A_{a t}} \leq 0$ when $\hat{\lambda}_{m t} \leq \hat{\lambda}_{m 0}$.

To show the second part of Proposition 3, we take logarithm of Eq. (18) and differentiate it with respect to $\varphi$. We get:

$$
\frac{\partial \hat{\lambda}_{m t}}{\partial \varphi} \frac{g^{\prime}\left(\hat{\lambda}_{m t}\right)}{g\left(\hat{\lambda}_{m t}\right)}=\frac{1}{\phi(\varphi)}-\frac{2}{\phi(\varphi)-\frac{1}{A_{a t} \hat{\lambda}_{m t}}}
$$

In Proposition 1, we showed that that $g^{\prime}\left(\hat{\lambda}_{m t}\right) \geq 0$ when $\hat{\lambda}_{m t} \leq \hat{\lambda}_{m 0}$. Since the right-hand side of Eq. (40) is negative, it follows that Eq. (18) has at least one solution which satisfies $\frac{\partial \hat{\lambda}_{m t}}{\partial \varphi} \leq 0$ when $\hat{\lambda}_{m t} \leq \hat{\lambda}_{m 0}$.

\section{References}

Bar, M., Leukhina, O.: On the time allocation of married couples since 1960. J. Macroecon. 33(4), 491-510 (2011)

Bar-Ilan, A., Blinder, A.S.: The life cycle permanent-income model and consumer durables. Ann. Econ. Stat. 9, 71-91 (1988)

Becker, G.S.: A Treatise on the Family. Harvard University Press, Cambridge (1991)

Benhabib, J., Rogerson, R., Wright, R.: Homework in macroeconomics: Household production and aggregate fluctuations. J. Polit. Econ. 99(6), 1166-1187 (1991)

Blau, F., Kahn, C.: Gender differences in pay. J. Econ. Perspect. 75-99, (2000)
Browning, M., Chiappori, P-A.: Efficient intra-household allocation: A general characterization and empirical tests. Econometrica. 66(6), 1241-1278 (1998)

Browning, M., Chiappori, P-A., Weiss, Y.: Family Economics. Cambridge University Press, (2011)

Burdett, K., Coles, M.G.: Marriage and class. Q. J. Econ. 1, 141-168 (1999)

Cardia, E.: Household technology and female labor force participation: Evidence from the U.S. Working Paper, University of Montreal, October 2010

Cavalcanti, T.V., Tavares, J.: Assessing the engines of liberation: Home appliances and female labor supply participation. Rev. Econ. Stat. 90(1), 81-88 (2008)

Coen-Pirani, D., Len, A., Lugauer, S.: The effect of household appliances on female labor force participation: Evidence from micro-data. Lab. Econ. 17(3), 503-513 (2010)

Dale, L., Fujita, S.K.: An analysis of the price elasticity of demand for household appliances. Lawrence Berkeley National Laboratory, University of California Berkeley, 1-19, (2008)

Day, T.: Capital-labor substitution in the home. Tech. Cult. 33, 302-327 (1992)

Dubin, J.A., McFadden, D.L.: An econometric analysis of residential electric appliance holdings and consumption. Econometrica. 52(2), 345-362 (1984)

Goldin, C.D.: Understanding the Gender Gap: An Economic History of American Women. Oxford University Press, (1990)

Goldin, C.D.: Career and family: College women look to the past. In: Blau, F.D., Ehrenberg, R.G. (eds.) Gender and Family Issues in the Workplace, pp. 20-58. New-York, Russell Sage Foundation, (1997)

Gordon, R.J.: The Measurement of Durable Goods Prices. University of Chicago Press, Chicago (1990)

Greenwood, J., Guner, N.: Marriage and divorce since WWII: Analyzing the role of technological progress on the formation of households. In: Acemoglu, D., Rogoff, K., Woodford, M. (eds.) Demography and the Economy, vol. 23, pp. 231-276. University of Chicago Press - NBER (2008)

Greenwood, J., Guner, N., Knowles, J.A.: More on marriage, fertility, and the distribution of income. Int. Econ. Rev. 44(3), 827-862 (2003)

Greenwood, J., Guner, N., Kocharkov, G., Santos, C.: Marry your like: Assortative mating and income inequality. Am. Econ. Rev. 104(5), 1-7 (2014)

Greenwood, J., Seshadri, A., Vandenbroucke, G.: The baby-boom and baby-bust. Amer. Econ. Rev. 95(1), 183-207 (2005a)

Greenwood, J.,Seshadri, A., Yorukoglu, M.: Engines of liberation. Rev. Econ. Stud. 72(1), 109-133 (2005b)

Jones, L.E., Manuelli, R., McGrattan, E.S.: Why are married women working so much? Federal Reserve Bank of Minneapolis Staff Report, May (2003)

Jones, L.E., Schoonbroodt, A., Tertilt, M.: Fertility theories: Can they explain the negative fertility-income relationship? In: Shoven, J.B. (ed.), Demography and the Economy, chapter 2. University of Chicago Press - NBER Volume, (2011)

McGrattan, E., Rogerson, R.: Changes in hours worked: 1950-2000. Q. Rev. Minneap. Fed. Reserve Bank. 28(1), 14-33 (2004)

McGrattan, E.R., Rogerson, R., Wright, R.: An equilibrium model of the business cycle with household production and fiscal policy. Int. Econ. Rev. 38(2), 267-290 (1997)

Miller, Jr., Laurence, H.: The demand for refrigerators: A statistical study. Rev. Econ Statistics. 42(2), 196-202 (1960)

Reiss, P.C., White, M.W.: Household electricity demand, revisited. Rev. Econ. Stud. 72(3), 853-883 (2005)

Roberts, K., Rupert, P. : The myth of the overworked american. Economic Commentary, Federal Reserve Bank of Cleveland, (1995) 
Rupert, P., Rogerson, R., Wright, R.: Homework in labor economics: Household production and intertemporal elasticity of substitution. J. Monet. Econ. 46(3), 557-580 (2000)

Schoonbroodt, A. Cross-sectional properties of female labor force participation: Theory and data. Working Paper, University of Minnesota, May 2004

Vandenbroucke, G.: Trends in hours: The U.S. from 1900 to 1950. J. Econ. Dynam. Control. 33(1), 237-249 (2009)

Sebastien Buttet is Associate Professor of Business at Guttman Community College in the City University of New York. Prior to this, he was Assistant Professor of Economics at Cleveland State University, $\mathrm{OH}$ and Visiting Professor of Economics at Long Island University, $\mathrm{NY}$. He received his PhD in economics from the University of Minnesota, Twin Cities, MN, USA in 2006.
Veronika Dolar is currently an Assistant Professor at the Department of Economics, Long Island University, LIU Post in Brookville, NY, USA. She received her PhD from the University of Minnesota, Twin Cities, USA in 2010. Her current research interests include health economics focusing on eating decision, nutrition and obesity, labor economics, as well as economic education and economics of education. 